\title{
The effect of 1,6-hexamethylenediamine on thermal stability and shale cutting recovery of heavy weight drilling fluids
}

\author{
Farough Agin ${ }^{1}$ Mohammad Amin Sharifnik ${ }^{2}$ - Zahra Azimi Dijvejin ${ }^{3}$. Alireza Nasiri ${ }^{1}$ (1) Majid Valizadeh $^{1}$. \\ Habibeh Shaikh Rostamabadi ${ }^{1}$
}

Received: 13 June 2018 / Accepted: 13 December 2018 / Published online: 19 December 2018

(c) The Author(s) 2018

\begin{abstract}
The capability of drilling fluid to endure high temperature and stabilize shale cuttings is important characteristics of drilling fluids. In this work, a combination of 1,6-hexamethylenediamine and polyanionic cellulose (PAC) was tested to observe the impact of 1,6-hexamethylenediamine on thermal stability of PAC and its influence on the shale cutting stability of drilling fluid. First, rheological parameters and filtration control were examined at four different temperatures $\left(325^{\circ} \mathrm{F}, 350^{\circ} \mathrm{F}, 375^{\circ} \mathrm{F}\right.$, and $400{ }^{\circ} \mathrm{F}$ ). Then, the cutting disintegration test was performed at $250^{\circ} \mathrm{F}$ to evaluate the effect of 1,6-hexamethylenediamine on shale cutting stability. Experimental results showed that adding 1,6-hexamethylenediamine to drilling fluids effectively increases the thermal stability of the rheological parameters of drilling fluids such as apparent viscosity, plastic viscosity, yield point, and gel strength up to $350^{\circ} \mathrm{F}$. It was also concluded that when 1,6-hexamethylenediamine is added to drilling fluid, the amount of fluid loss is in acceptable range up to $375^{\circ} \mathrm{F}$. Finally, the results indicated that 1,6-hexamethylenediamine significantly increases the shale cutting recovery.
\end{abstract}

Keywords PAC $\cdot 1,6-$ Hexamethylenediamine $\cdot$ Thermal stability $\cdot$ Shale recovery $\cdot$ Heavy weight mud

\section{Introduction}

Drilling fluid is an important element in drilling operations. Improper design of drilling fluids causes significant problems during drilling operations. Drilling fluid properties such as $\mathrm{pH}$, rheology, and filtration control should be properly evaluated to fulfill its substantial functions. The most important functions of drilling fluids are cooling the bottom hole assembly, balancing the formation pressure, transporting and suspending cuttings, and minimizing formation damage (Agin et al. 2018; Moraveji et al. 2017; Dhiman 2016; Kafashi et al. 2017a, b; Nasiri et al. 2017).

Alireza Nasiri

nasiriar@ ripi.ir

1 Research Institute of Petroleum Industry (RIPI), West Blvd., Near Azadi Sports Complex, Tehran 14857-33111, Iran

2 School of Mining Engineering, College of Engineering, University of Tehran, Tehran 14174-66191, Iran

3 Department of Chemical Engineering, Tarbiat Modares University, Jalal Al-e Ahmad Avenue, Tehran 14115-111, Iran
Drilling fluids are classified into four main categories: water-based mud (WBM), oil-based mud (OBM), gas-drilling mud, and foam-drilling mud (Dhiman 2016). Due to environmentally friendly properties and low cost of WBMs, approximately $80 \%$ of drilling operations are carried out by the first type (Dhiman 2016). Thus, improving the properties of WBMs is of most priority (Shakib et al. 2016; Davoodi et al. 2017).

Different properties of WBM can be improved using polymers. Polymers are widely utilized to control filtration, improve rheological parameters, enhance cutting transport capacity, and improve shale recovery (Halali et al. 2016). PAC, xanthan gum (XGD), carboxymethyl cellulose (CMC), starch, and partially-hydrolyzed polyacrylamide (PHPA) are the most commonplace polymers in drilling industry (Thomas 1982; Plank and Gossen 1991; Oswald et al. 2006; Balestrini et al. 2009; Kelessidis et al. 2013; Toka and Toka 2015; Villada et al. 2017). One of the disadvantages of polymers is their low performance in high-temperature and high-pressure (HPHT) conditions which bring about the degradation of polymers (Halali et al. 2016). Thomas (1982) showed that the thermal stabilities of starch and CMC are in the range of $200-225^{\circ} \mathrm{F}$ and $275-300^{\circ} \mathrm{F}$, respectively. 
Plank and Gossen (1991) showed that the thermal stability of PAC is about $300^{\circ} \mathrm{F}$. Toka and Toka (2015) demonstrated that the thermal stability of XGD and CMC is up to $300^{\circ} \mathrm{F}$ and $250{ }^{\circ} \mathrm{F}$, respectively.

Nanoparticles and amines are routinely used to increase the thermal stability of common used drilling polymers. Nanoparticles are mostly used to improve drilling fluids rheology, decrease fluid loss, reduce torque and drag, lubricate drilling bits, and finally increase thermal stability (Hoelscher et al. 2012; Zakaria et al. 2012; Halali et al. 2016; Mozaffari et al. 2017a, b). These nanoparticles include, but are not limited to, multi-walled carbon nanotube (MWCNT), nanosilica, nano-copper oxide, nano-clay, nano-CMC, cellulose nanocrystals (CNCs), nano-bentonite, nano-calcium carbonate, nano-zinc oxide, and nano-graphene (Fereydouni et al. 2012; Abdou et al. 2013; William et al. 2014; Li et al. 2015; Abduo et al. 2016; Ismail et al. 2016; Jain et al. 2016; Aftab et al. 2017; Kafashi et al. 2017a, b; Mohammed 2017a, b; Noah et al. 2017; Mozaffari et al. 2018; Azimi Dijvejin et al. 2018). However, using nanoparticles as an additive in drilling fluids has several disadvantages. First, nanoparticles are expensive, which make them less practical in field applications (Sensoy et al. 2009; Abdo and Haneef 2010). The dispersion problem of nanoparticles in drilling fluids is another disadvantage of these additives. The previous experimental studies of nano-based drilling fluids mostly made a use of the ultrasonic method to effectively disperse nanoparticles (Wong and De Leon 2012; William et al. 2014; Ponmani et al. 2016). However, this method is not applicable in field applications.

Amines are widely used as an additive in drilling fluids to improve the drilling fluid properties such as rheology, filtration control, and shale stability. Amines contain hydrogen molecules in their branches, which form hydrogen bonds with the hydrogen molecules of polymers. This bonding results in higher thermal stability of the mixture (Mozaffari et al. 2015; Halali et al. 2016; Nasiri et al. 2018). In addition, amines form a layer on the surface of shale cuttings, which encapsulate them. This prohibits the disintegration of shale cuttings (Van Oort 2003; Du et al. 2018). A literature review of the available studies on the effect of amines on the properties of drilling fluids is presented in Table 1. As can be seen, in the previous studies, the thermal stability of drilling fluids containing amines was not higher than $320^{\circ} \mathrm{F}$. However, in some locations such as US Gulf Coast and the North Sea, drilling wells with a bottom hole temperature of $350^{\circ} \mathrm{F}$ are common (Baller 1991; Adamson et al. 1993). The main goal of this study is to increase the thermal stability of a drilling fluids containing PAC up to $350{ }^{\circ} \mathrm{F}$.

In this work, 1,6-hexamethylenediamine has been used in a heavy weight drilling fluid (135 pcf) containing PAC to increase thermal stability and shale stability of drilling fluid. Rheological parameters and filtration control were evaluated at four different temperatures $\left(325^{\circ} \mathrm{F}, 350{ }^{\circ} \mathrm{F}, 375^{\circ} \mathrm{F}\right.$, and $400{ }^{\circ} \mathrm{F}$ ). Results indicate that adding amine to drilling fluid effectively improves rheological parameters and filtration control at elevated temperatures. The shale cutting disintegration test was also carried out. The outcomes showed that adding amine significantly increases shale stability.

\section{Experimental}

\section{Materials}

In this study, a low-viscosity grade of PAC (also known as PAC-LV) was used. This water-soluble polymer is mostly used to improve rheology, shale stability, and filtration control properties of drilling fluids (Thomas 1982; Plank and Gossen 1991; Oswald et al. 2006; Kelessidis et al. 2013; Toka and Toka 2015; Davoodi et al. 2017). According to the API-13B standard, a high-quality PAC-LV should have special physical properties (API 2003). It should be noted that in this work, the used PAC-LV has passed all API requirements. Figure 1a shows the chemical structure of PAC-LV. Barium sulfate or barite is the other additive which is used in this study (API 2003). This additive is routinely used as weighting agent in drilling fluids and cement slurries. Again, the API-13B-1 standard was used to determine the physical properties of the used barite and ensure its high performance (API 2003).

1,6-Hexamethylenediamine was purchased from SigmaAldrich (Missouri, United States). The boiling point of 1,6-hexamethylenediamine is $401^{\circ} \mathrm{F}$ at $760 \mathrm{~mm} \mathrm{Hg}$, while its melting point is $108^{\circ} \mathrm{F}$. In addition, its molecular weight is $116.208 \mathrm{~g} / \mathrm{mol}$. This material is soluble in water. When 1,6-hexamethylenediamine is added to water, a colorless solution is obtained. 1,6-Hexamethylenediamine has two hydrogen bond donor counts and two hydrogen bond acceptor counts. Figure $1 \mathrm{~b}$ illustrates the chemical structure of 1,6-hexamethylenediamine.

\section{Drilling fluid formulation and design}

In this study, the formulation of heavy weight drilling fluid provided by the National Iranian South Oil Company (NISOC) was used. First, $10 \mathrm{~g}$ of PAC were slowly added to $350 \mathrm{cc}$ of saturated salt water and stirred for $20 \mathrm{~min}$. Afterwards, $697.6 \mathrm{~g}$ of Barite were added as weighting material and mixed for $10 \mathrm{~min}$. It should be noted that the density of saturated salt water was 75 pcf. However, after adding Barite, the drilling fluid density raised up to $135 \mathrm{pcf}$. Finally, to investigate the effect of 1,6-hexamethylenediamine on drilling fluid properties, four different volume concentrations (1, 2,4 , and $6 \%$ ) of this additive were added to 135 pcf drilling 
Table 1 Literature review of the available studies on the effect of amines on properties of drilling fluids

\begin{tabular}{|c|c|c|c|c|}
\hline References & Amine type & Polymer type & Temperature & Result \\
\hline Nasiri et al. (2018) & Monoethanolamine & Starch & $320^{\circ} \mathrm{F}$ & $\begin{array}{l}\text { Improve rheology } \\
\text { Reduce fluid loss }\end{array}$ \\
\hline Du et al. (2018) & $\begin{array}{l}\text { Combination of diethylamine, } \\
\text { 1-bromotetradecane, and } \\
\text { 1,2-dibromoethane }\end{array}$ & - & $250^{\circ} \mathrm{F}$ & Improve shale recovery \\
\hline $\begin{array}{l}\text { Gholizadeh-Doonechaly et al. } \\
\text { (2009); Patel (2009) }\end{array}$ & Amine based inhibitor & PHPA & $200^{\circ} \mathrm{F}$ & $\begin{array}{l}\text { Improve rheology } \\
\text { Reduce fluid loss } \\
\text { Improve shale recovery }\end{array}$ \\
\hline Patel (2009) & $\begin{array}{l}\text { Modified oligometric cationic } \\
\text { amines }\end{array}$ & - & $250^{\circ} \mathrm{F}$ & Improve shale recovery \\
\hline Beg et al. (2018) & $\begin{array}{l}\text { Polytertiary amines (PTA) and } \\
\text { Polyquaternary amines (PQA) }\end{array}$ & Copolymer & $212^{\circ} \mathrm{F}$ & $\begin{array}{l}\text { Improve rheology } \\
\text { Reduce fluid loss } \\
\text { Improve shale recovery }\end{array}$ \\
\hline Van Oort et al. (1997) & Polyglycols & $\mathrm{XC} / \mathrm{PAC} / \mathrm{KCl} / \mathrm{PHPA}$ & $230^{\circ} \mathrm{F}$ & $\begin{array}{l}\text { Improve rheology } \\
\text { Reduce fluid loss }\end{array}$ \\
\hline Van Oort et al. (1997) & Polyglycols & $\begin{array}{l}\text { PAC-LV } \\
\text { CMC-LV }\end{array}$ & $266^{\circ} \mathrm{F}$ & $\begin{array}{l}\text { Improve rheology } \\
\text { Reduce fluid loss }\end{array}$ \\
\hline Audibert and Argillier (1995) & $\begin{array}{l}\text { Acrylamidemethylpropane } \\
\text { sulfonate (AMPS) }\end{array}$ & Copolymer & $248^{\circ} \mathrm{F}$ & $\begin{array}{l}\text { Improve rheology } \\
\text { Reduce fluid loss }\end{array}$ \\
\hline Onuoha et al. (2011) & $\begin{array}{l}\text { Diamino butane and diamino } \\
\text { hexane }\end{array}$ & Chlorides and hydroxides & $250^{\circ} \mathrm{F}$ & Improve shale recovery \\
\hline Lv et al. (2014) & Organic Amine & - & $248^{\circ} \mathrm{F}$ & $\begin{array}{l}\text { Improve rheology } \\
\text { Reduce fluid loss, and improve } \\
\text { shale recovery }\end{array}$ \\
\hline Xie et al. (2017) & $\begin{array}{l}\text { Polyethyleneamine and 1,6-hexa- } \\
\text { methylenediamine }\end{array}$ & - & $194^{\circ} \mathrm{F}$ & $\begin{array}{l}\text { Improve rheology } \\
\text { Reduce fluid loss, and improve } \\
\text { shale recovery }\end{array}$ \\
\hline $\begin{array}{l}\text { Zhong et al. (2012); Qu et al. } \\
\text { (2009) }\end{array}$ & $\begin{array}{l}\text { Poly (oxypropylene)-amidoam- } \\
\text { ine }\end{array}$ & - & $250^{\circ} \mathrm{F}$ & Improve shale recovery \\
\hline Bruton and McLaurine (1993) & Amino acids & - & $250^{\circ} \mathrm{F}$ & Improve shale recovery \\
\hline Wang et al. (2011) & Poly (oxypropylene) diamines & PAC & $250^{\circ} \mathrm{F}$ & Improve shale recovery \\
\hline $\begin{array}{l}\text { Zhong et al. (2011, 2012, 2013, } \\
\text { 2015a, b, 2016) }\end{array}$ & $\begin{array}{l}\text { Polyetheramines, polyetherdi- } \\
\text { amines, poly (oxpropylene)- } \\
\text { amidoamine, and polyami- } \\
\text { doamine dendrimers }\end{array}$ & - & $250^{\circ} \mathrm{F}$ & Improve shale recovery \\
\hline Peng et al. (2013) & Polyetheramine & - & $250^{\circ} \mathrm{F}$ & Improve shale recovery \\
\hline
\end{tabular}

Fig. 1 Chemical structure of a PAC and b 1,6-hexamethylenediamine (Plank and Gossen 1991; Patel 2009)
A

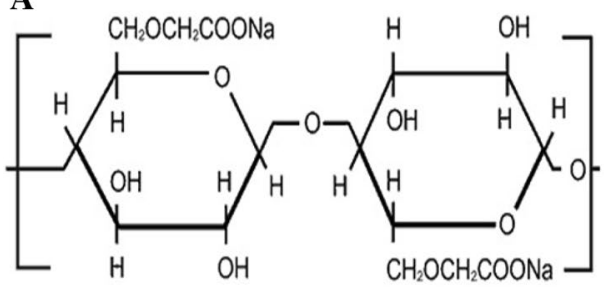

B<smiles>NCCCCCCN</smiles>

fluid. The composition of various drilling fluids is shown in Table 2.

\section{Shale characterization}

Shale is mainly consisting of quartz, clay, silicate, and carbonate minerals. High concentrations of clay minerals increase the tendency of shale to absorb water and lead to swelling and dispersion. To investigate the capability of 1,6-hexamethylenediamine on the shale cutting recovery, shale sample of Pabdeh formation was used. The tendency of shale sample to absorb water was examined by placing a shale sample in fresh water. Figure 2 shows the disintegration of shale sample in the presence of water after $24 \mathrm{~h}$. As 
Table 2 Composition of the used drilling fluids

\begin{tabular}{llllll}
\hline Mud composition & \multicolumn{5}{l}{ Sample number } \\
\cline { 2 - 6 } & 1 & 2 & 3 & 4 & 5 \\
\hline Salt saturated water & $350 \mathrm{cc}$ & $350 \mathrm{cc}$ & $350 \mathrm{cc}$ & $350 \mathrm{cc}$ & $350 \mathrm{cc}$ \\
PAC & $10 \mathrm{~g}$ & $10 \mathrm{~g}$ & $10 \mathrm{~g}$ & $10 \mathrm{~g}$ & $10 \mathrm{~g}$ \\
Barite & $697.6 \mathrm{~g}$ & $697.6 \mathrm{~g}$ & $697.6 \mathrm{~g}$ & $697.6 \mathrm{~g}$ & $697.6 \mathrm{~g}$ \\
$\begin{array}{l}\text { 1,6-Hexamethylenedi- } \\
\text { amine }\end{array}$ & 0 & $3.5 \mathrm{cc}$ & $7 \mathrm{cc}$ & $14 \mathrm{cc}$ & $21 \mathrm{cc}$ \\
\hline
\end{tabular}

it can be seen, the Pabdeh shale sample is highly unstable in fresh water.

X-ray diffraction (XRD) analysis was carried out using (Philips X'Pert MPD, Netherlands) device to determine the mineral compositions of shale sample. Figure 3 shows the XRD pattern of shale sample. As it can be observed, illite is the main constituent of shale sample due to the high number of small peaks. In addition, X-ray fluorescence (XRF) analysis was carried out using (Philips PW2404, Netherlands) device to specify the chemical compositions of shale sample (Table 3). It should be noted that for $2 \theta<30^{\circ}$, the only mineral is illite and the other minerals are above $30^{\circ}$. In Fig. 3, pink color depicts illite, blue color shows calcite peaks, black color illustrates quartz, and green color demonstrates dolomite.

\section{Apparatus setup and procedures}

\section{General drilling fluid tests}

Thermal stability of drilling fluids was determined after aging at four different temperatures $\left(325^{\circ} \mathrm{F}, 350^{\circ} \mathrm{F}, 375^{\circ} \mathrm{F}\right.$, and $400^{\circ} \mathrm{F}$ ) for $16 \mathrm{~h}$. It should be noted that in this study, high-temperature aging cells containing drilling fluids were placed into FANN roller oven (FANN, USA) to be exposed to desired temperatures. Rheological properties of drilling fluids after hot rolling were measured according to API
Fig. 2 Behavior of Pabdeh shale sample: a before contacting with water and $\mathbf{b}$ after $24 \mathrm{~h}$ contacting with water
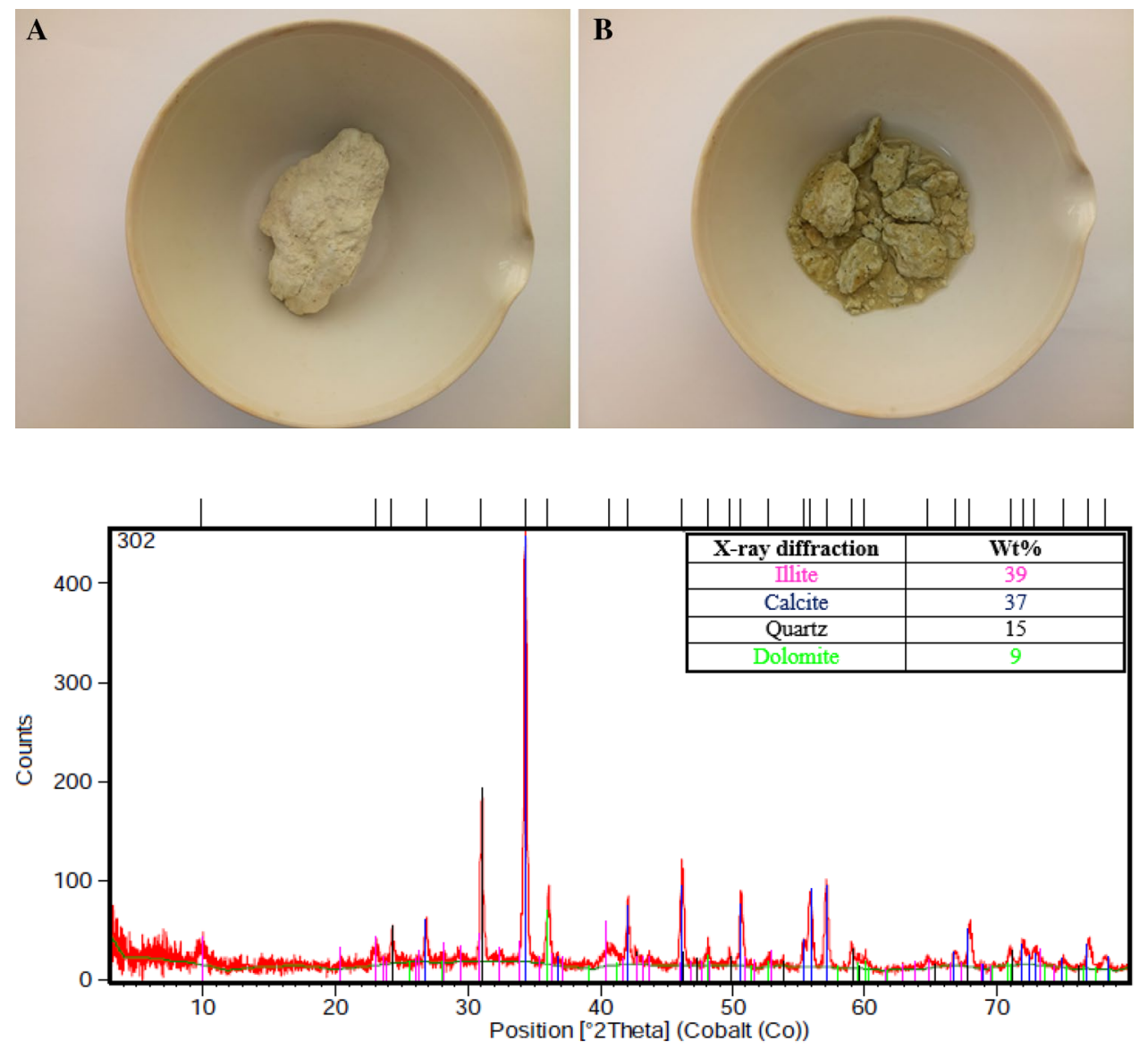

Fig. 3 XRD pattern of shale sample

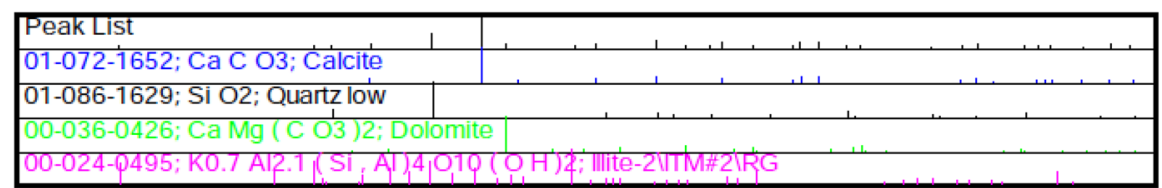


Table 3 XRF of shale for chemical analysis

\begin{tabular}{lll}
\hline S. no. & Element & Percentage \\
\hline 1 & $\mathrm{Na}_{2} \mathrm{O}$ & 0.35 \\
2 & $\mathrm{SO}_{3}$ & 0.08 \\
3 & $\mathrm{TiO}_{2}$ & 0.44 \\
4 & $\mathrm{MgO}$ & 6.72 \\
5 & $\mathrm{Cl}$ & 0.28 \\
6 & $\mathrm{Fe}_{2} \mathrm{O}_{3}$ & 6.56 \\
7 & $\mathrm{Al}_{2} \mathrm{O}_{3}$ & 10.18 \\
8 & $\mathrm{~K}_{2} \mathrm{O}$ & 2.78 \\
9 & $\mathrm{L.O} . \mathrm{I}$ & 10.04 \\
10 & $\mathrm{SiO}_{2}$ & 29.39 \\
11 & $\mathrm{CaO}$ & 33.18 \\
12 & $\mathrm{La} \mathrm{\&} \mathrm{Lu}$ & $<1$ \\
\hline
\end{tabular}

standard using a FANN 35 Viscometer (FANN, USA) at $140{ }^{\circ} \mathrm{F}$ (API 2003). To measure the amount of fluid loss, the API standard filter press apparatus (FANN, USA) was used. A highly sensitive digital $\mathrm{pH}$ meter (ACCSEN, Spain) was used to determine the $\mathrm{pH}$ values of drilling fluids.

\section{Shale cutting disintegration test}

Routinely, shale cuttings split during the drilling operations of shale formations which cause severe changes in drilling fluid properties. As a result, analyzing the shale cutting stability is an important process during designing of drilling fluid for shale formations. In this study, $20 \mathrm{~g}$ of shale were added to $350 \mathrm{ccs}$ of drilling fluids and hot rolled for $16 \mathrm{~h}$ at $250{ }^{\circ} \mathrm{F}$ according to API standards. Afterwards, the hot rolling cells were cooled down to room temperature. The cooled drilling fluid was then sieved through a fine sieve (mesh 35, $500 \mathrm{~nm}$ ). Next, to remove impurities, the mesh 35 sieve was thoroughly washed with a saturated potassium chloride solution. The shale cuttings were then washed with warm water and dried in an oven at $105^{\circ} \mathrm{C}\left(221^{\circ} \mathrm{F}\right)$. Finally, the dried shale cuttings were weighed and the results were used to determine the shale recovery performance of different drilling fluids.

\section{Results and discussion}

As it was discussed in the previous sections, combination of PAC and 1,6-hexamethylenediamine was used in heavy weight drilling fluid to improve rheological parameters, control filtration, and increase shale cutting stability. The interaction between PAC and 1,6-hexamethylenediamine leads to formation of polyamide. Figure 4 illustrates the polyamide structure obtained from the reaction of PAC and 1,6-hexamethylenediamine. Polyamides are produced either by the reaction of a dyadic with a diamine or by

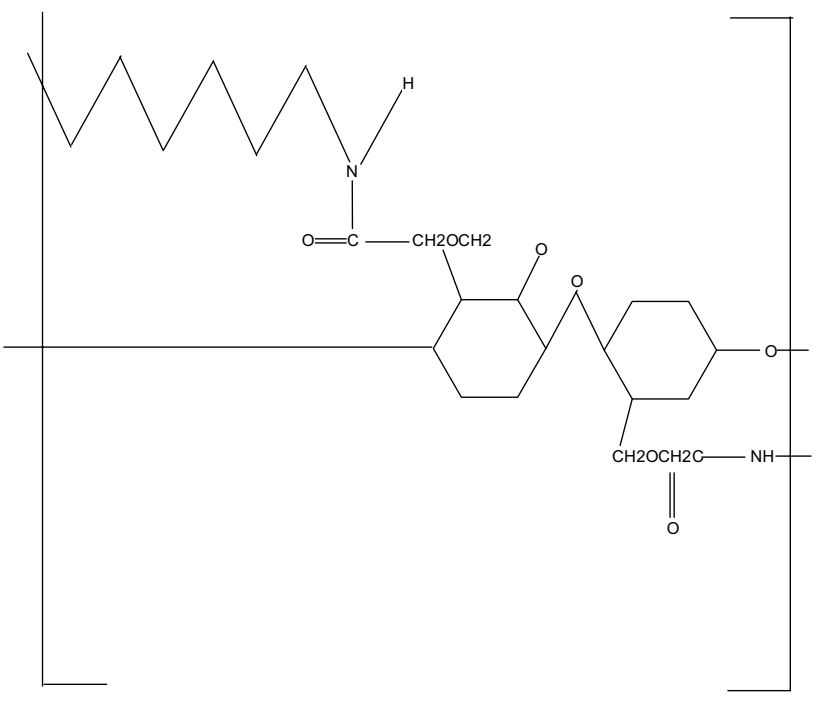

Fig. 4 Scheme of polyamide structure produced from the reaction between 1,6-hexamethylenediamine and PAC

ring-opening polymerization of lactams. They can be aliphatic, semi-aromatic, or fully aromatic thermoplastics. The fully aromatic structure and the strong hydrogen bonds between the aramid chains result in high melting points (generally above their decomposition temperature $>750 \mathrm{~K}$ ), ultra-high tensile strength at low weight, and excellent flame and heat resistance as well as good dimensional stability and solvent resistance at room and elevated temperature. The aliphatic polyamides are produced on a much larger scale than the fully aromatic polyamides and are the most important class of engineering thermoplastics. They are amorphous or only moderately crystalline when injection molded, but the degree of crystallinity can be much increased for fiber and film applications by orientation via mechanical stretching (Van Krevelen and Te Nijenhuis 2009). As it is mentioned, polyamides have ultra-high tensile strength which in solution causes the increase of viscosity.

The concentration of PAC would certainly affect the rheological parameters and filtration. In the laboratory, different concentrations of PAC were tested to select the optimal value of PAC for the following tests. Figure 5 shows the different values of PAC from 6 to $12 \mathrm{lb}$. As it can be concluded, $10 \mathrm{lb}$ and $12 \mathrm{lb}$ have a better effect on rheological parameters and filtration. Fluid losses are decreased compare to $6 \mathrm{lb}$ and $8 \mathrm{lb}$. In addition, plastic viscosity, apparent viscosity, and yield point have improved. However, the changes of $\mathrm{pH}$ are infinitesimal. Therefore, between 10 and $12 \mathrm{lb}, 10 \mathrm{lb}$ of PAC was selected. As it can be seen, both concentrations have approximately similar effect. Thus, the lower concentration was selected as the base of the further experiments.

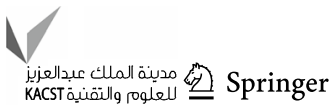


Fig. 5 Comparison of different concentrations of PAC

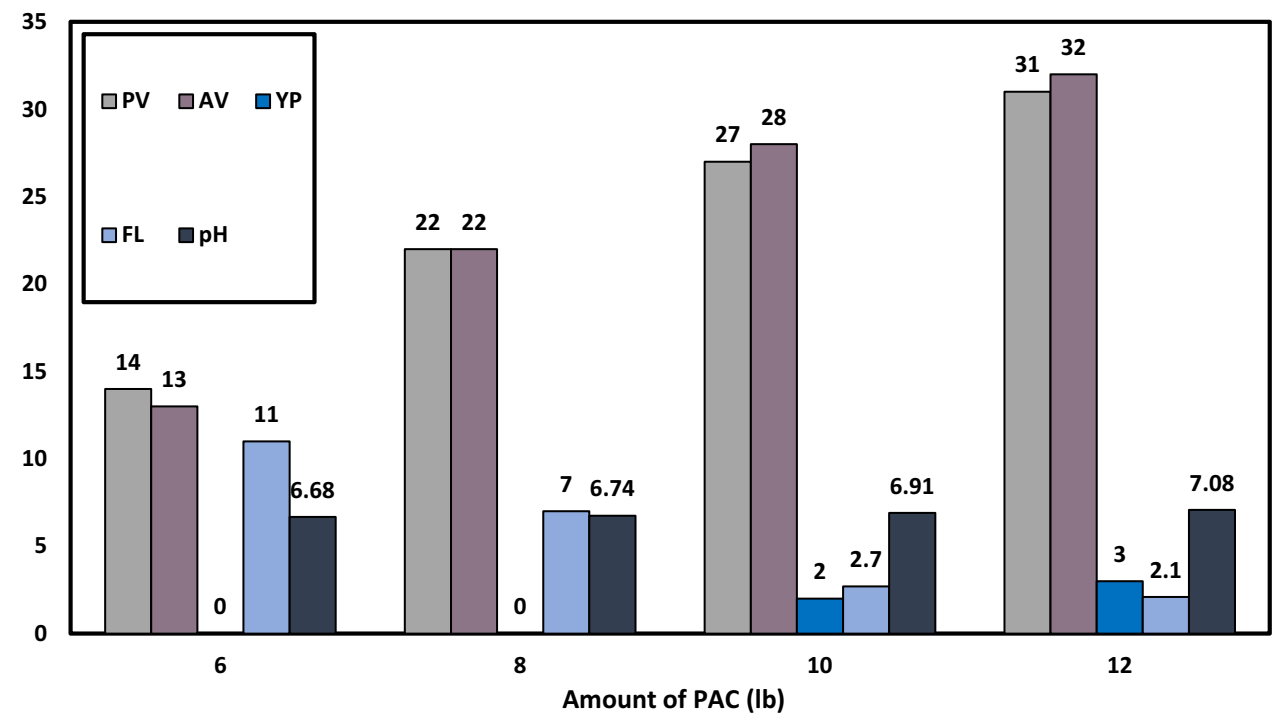

\section{Filtration control test}

Filtration rate is one of the most important properties of drilling fluids. High rates of filtration increase the mud thickness, which lead to operational problems such as stuck pipe (Nasiri et al. 2018). After hot rolling of drilling fluids for $16 \mathrm{~h}$, API filtration test was conducted. According to Fig. 6 , the amount of fluid loss of the base mud is equal to $2.7 \mathrm{ccs}$ at $325^{\circ} \mathrm{F}$. However, fluid loss of drilling fluid rises up to $28 \mathrm{ccs}$ at $350{ }^{\circ} \mathrm{F}$. When $1(\mathrm{v} / \mathrm{v} \%)$ of 1,6-hexamethylenediamine is used in heavy weight drilling fluid, fluid loss is in acceptable range up to $350^{\circ} \mathrm{F}$. However, above $350{ }^{\circ} \mathrm{F}$, fluid loss dramatically increases. When 2,4 , and $6(\mathrm{v} / \mathrm{v} \%)$ of the amine were used, fluid loss is controlled up to $375^{\circ} \mathrm{F}$.

It should also be emphasized that above $375^{\circ} \mathrm{F}$, the amount of fluid loss is increased and reached to $48 \mathrm{ml}$. As a result, the combination of PAC and 1,6-hexamethylenediamine could not effectively control fluid loss of heavy weight drilling fluid above $375{ }^{\circ} \mathrm{F}$. These outcomes clearly show that the mixture of amine and PAC can be used in HPHT wells, where PAC loses its ability in controlling fluid loss at high temperatures.

\section{pH control}

Low values of $\mathrm{pH}$ cause severe problems such as corrosion of equipment in drilling operations (Nasiri et al. 2018). From Fig. 7, it can be concluded that adding amine to drilling fluid, dramatically increases the $\mathrm{pH}$ value, while the base mud has low $\mathrm{pH}$ value. Note that the $\mathrm{pH}$ values of drilling fluids containing 1,6-hexamethylenediamine are between 9.4 and 11.2. However, $\mathrm{pH}$ values in base mud are between 5.9 and 7 .

Increasing the $\mathrm{pH}$ value of drilling fluids containing amine is mainly because of nitrogen atom. In 1,6-hexamethylenediamine compound, the nitrogen atom in the amine group contains $p$ electron which easily accepts proton and
Fig. 6 Effect of the combination of 1,6-hexamethylenediamine and PAC on fluid loss

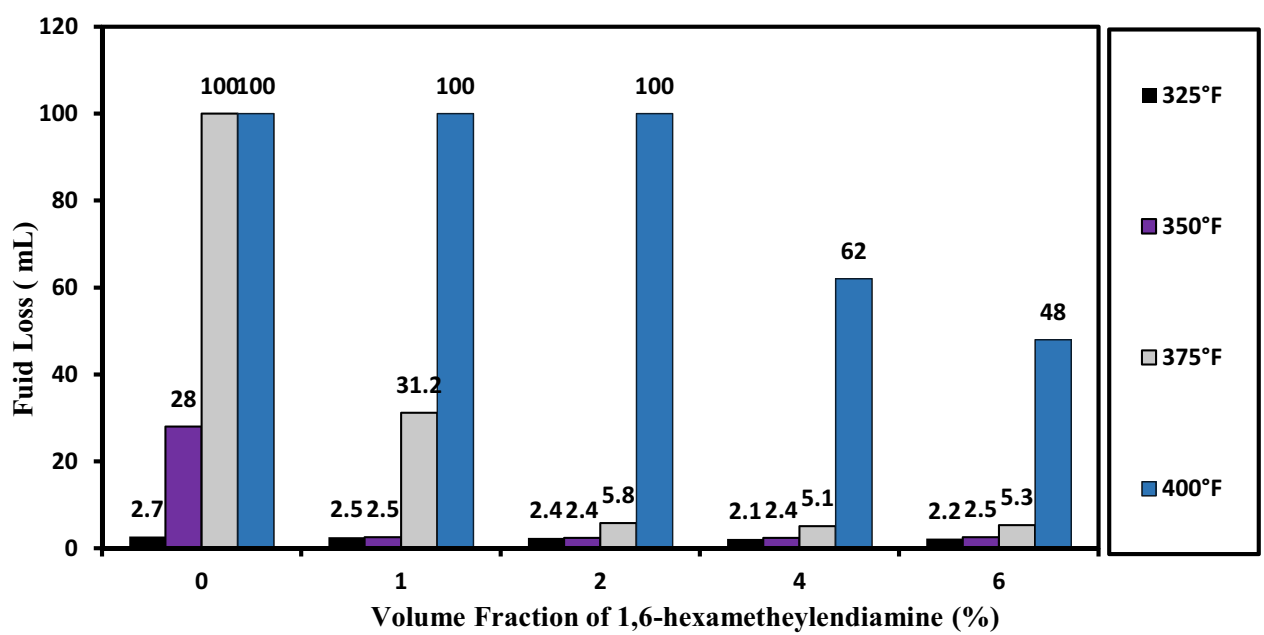


Fig. 7 Effect of the combination of 1,6-hexamethylenediamine and $\mathrm{PAC}$ on $\mathrm{pH}$

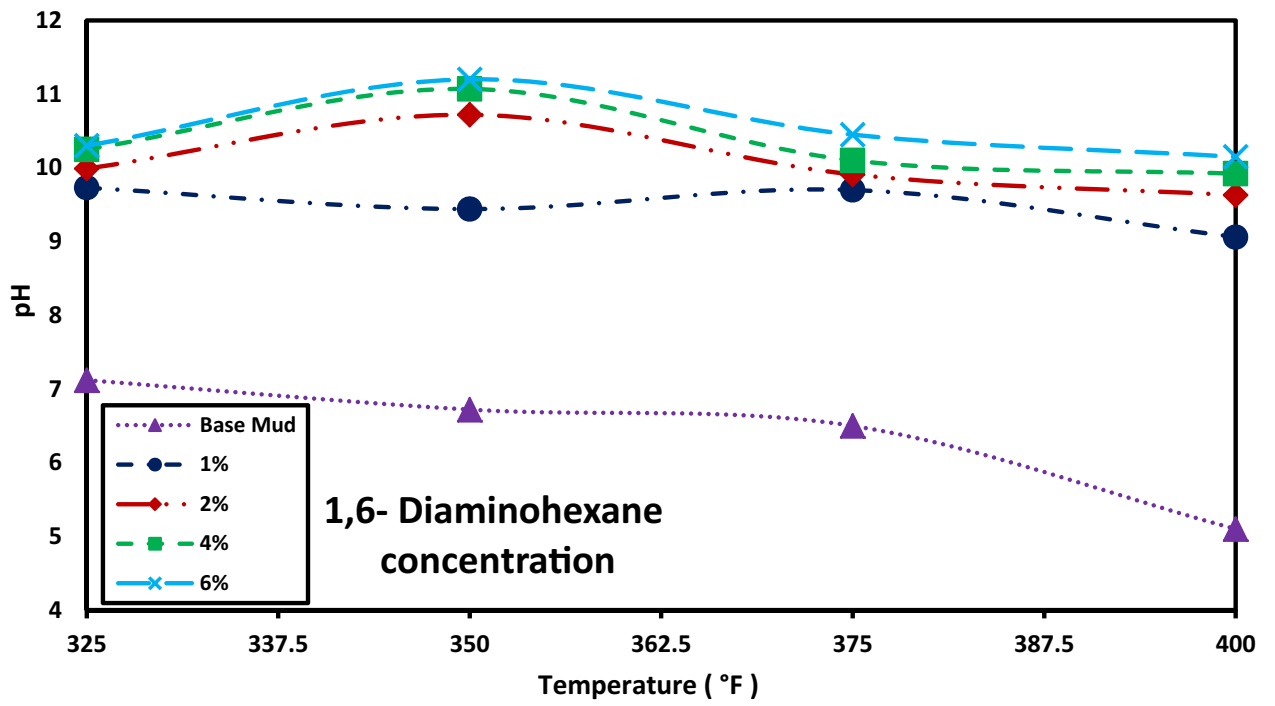

becomes positively charged. The equilibrium formula is as follows (Zhong et al. 2011):

$\mathrm{RNH}_{2}+\mathrm{H}_{2} \mathrm{O} \rightleftarrows \mathrm{RNH}_{3}^{+}+\mathrm{OH}^{-}$.

In addition, it should be mentioned $\mathrm{pH}$ rises in the solution according to Henderson-Hasselbach equation (Zhong et al. 2011):

$$
\begin{gathered}
\mathrm{pH}=\mathrm{p} K_{\mathrm{a}}+\log \left\{\left[\mathrm{R}-\mathrm{NH}_{2} /\left[\mathrm{R}-\mathrm{NH}_{3}^{+}\right]\right\},\right. \\
\text {where } \mathrm{p} K_{\mathrm{a}}=-\log K_{\mathrm{a}} .
\end{gathered}
$$

\section{Rheology testing}

Rheological parameters represent the capability of drilling fluid to suspend cuttings, cycle the drilling fluid, and clean wellbore. Apparent viscosity and plastic viscosity represent the ability of drilling fluids to cycle in the wellbore. Yield point is a significant factor in suspending drilling cuttings and effective hole cleaning. Gel strength is another property of drilling fluids which reflect the ability of suspending cuttings in static state (Dhiman 2016; Nasiri et al. 2017, 2018; Shahbazi et al. 2018; Alemdar et al. 2005). Drilling fluids with low rheological parameters are not able to perform their duties. As it can be seen in Figs. 8, 9, 10, 11, and 12, the rheological properties of heavy weight drilling fluids depend on the rolling temperatures and volume concentration of 1,6-hexamethylenediamine. As it is clear, the amount of apparent viscosity, plastic viscosity, yield point, and gel strength of drilling fluids which are rolled at 375 and $400{ }^{\circ} \mathrm{F}$ are much lower than the rheological properties of the drilling fluids which are rolled at 325 and $350{ }^{\circ} \mathrm{F}$. As a result, the rheological properties are only stable up to $350^{\circ} \mathrm{F}$.

The concentration of amine also affects the rheological properties. As it can be seen, the rheological properties of
Fig. 8 Effect of the combination of 1,6-hexamethylenediamine and PAC on plastic viscosity

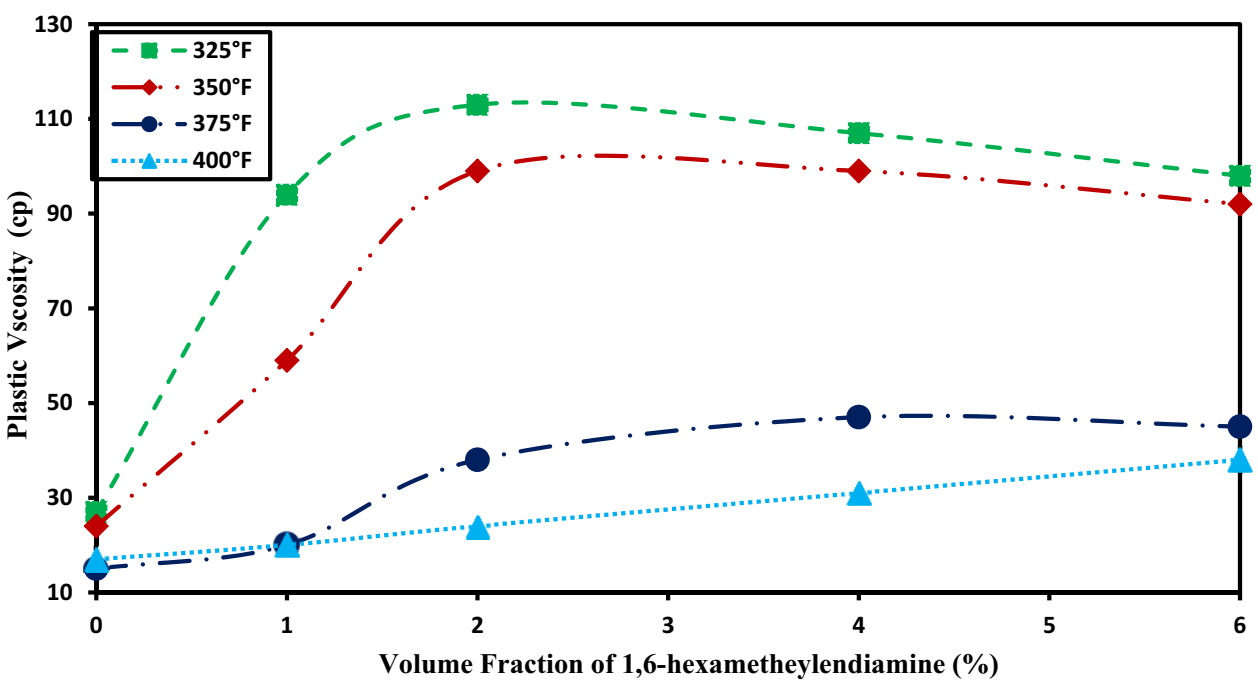

Volume Fraction of 1,6-hexametheylendiamine (\%) 
Fig. 9 Effect of the combination of 1,6-hexamethylenediamine and PAC on apparent viscosity
Fig. 10 Effect of the combination of 1,6-hexamethylenediamine and PAC on yield point

Fig. 11 Effect of the combination of 1,6-hexamethylenediamine and PAC on initial gel strength
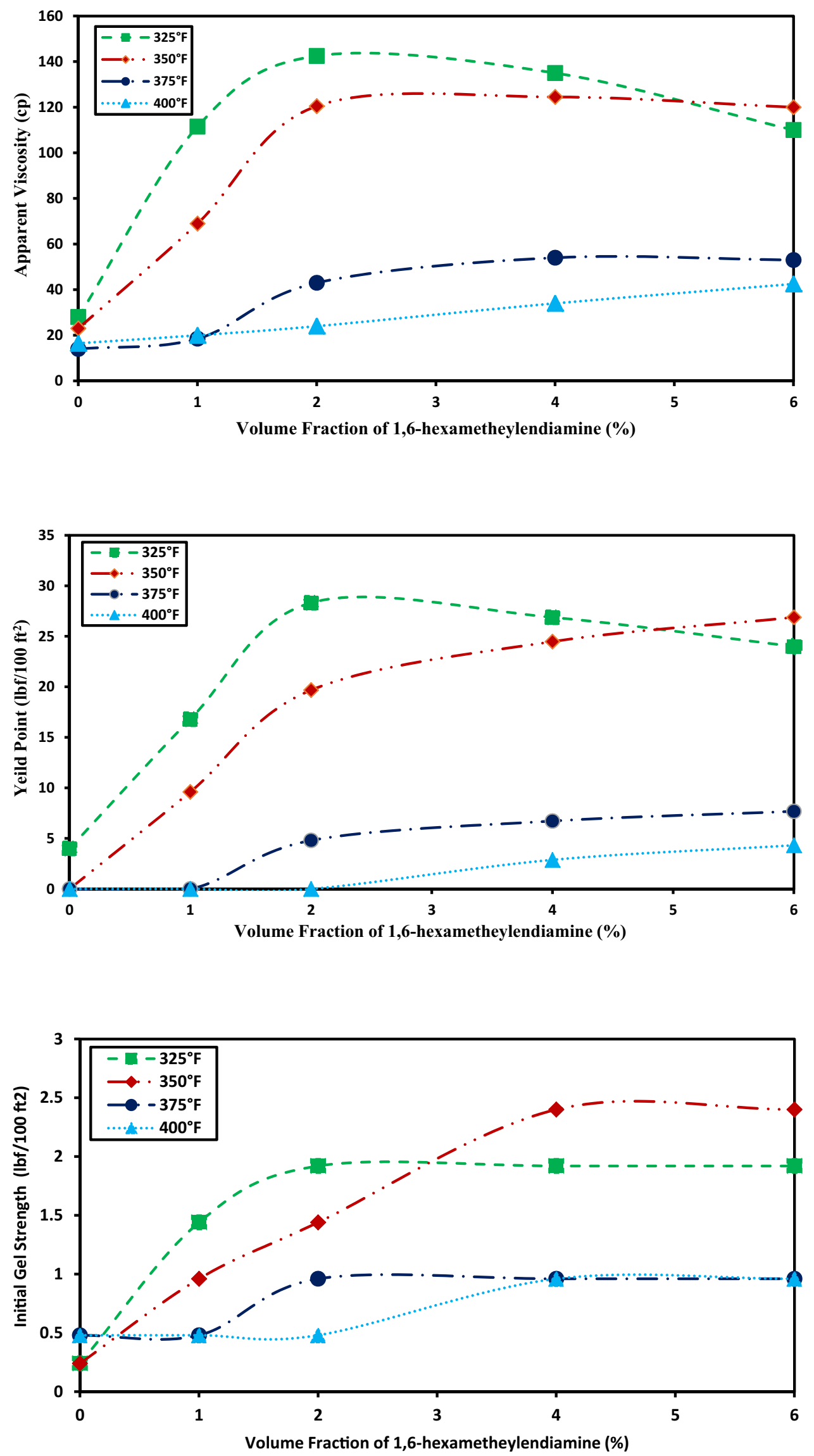
Fig. 12 Effect of the combination of 1,6-hexamethylenediamine and PAC on gel strength $10 \mathrm{~min}$

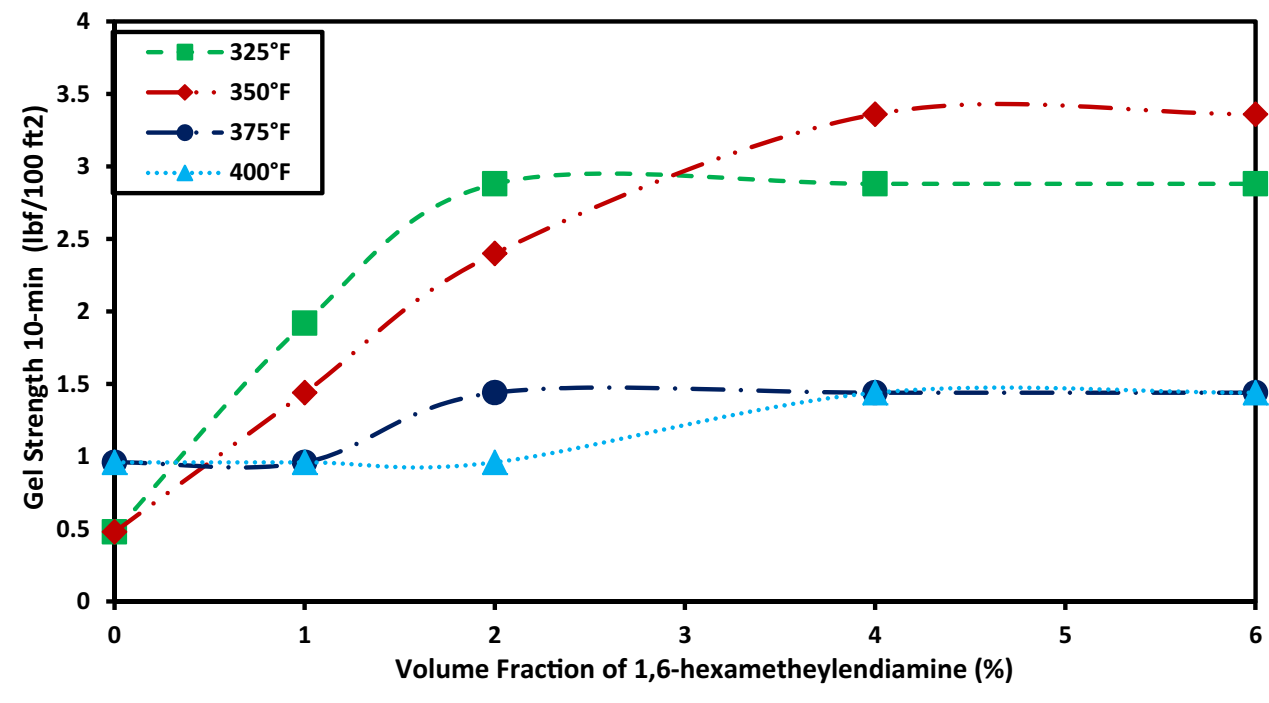

based drilling fluid are tremendously improved by adding amine. It should also be emphasized that the rheological properties of drilling fluids containing 2, 4, and 6 (v/v \%) of 1,6-hexamethylenediamine are almost equal. As a result, 2 (v/v \%) can be chosen as the optimum concentration of 1,6-hexamethylenediamine for improving the rheological properties of heavy weight drilling fluids. Therefore, the higher concentrations of 1,6-hexamethylenediamine are not economically justifiable.

\section{Shale cutting disintegration test}

As it is mentioned above, the effect of 1,6-hexamethylenediamine was tested on the stability of shale cuttings. According to API, $20 \mathrm{~g}$ of shale cuttings were added to $350 \mathrm{ccs}$ of drilling fluids. After that they were hot rolled for $16 \mathrm{~h}$ at $250^{\circ} \mathrm{F}$. Figure 11 shows the shale recovery of various amounts of 1,6-hexamethylenediamine against base mud. Shale recovery of base mud was relatively low. However, adding one percentage of 1,6-hexamethylenediamine has extremely increased shale recovery from 17.2 to $76.1 \%$. From Fig. 13, it can be understood that the drilling fluid with 6 (v/v \%) of 1,6-hexamethylenediamine has the highest shale recovery with the amount of $83.4 \%$. However, the difference between shale recovery of 2 (v/v \%) and $6(\mathrm{v} / \mathrm{v} \%)$ is relatively low. Consequently, the optimal volume fraction of 1,6-hexamethylenediamine is $2(\mathrm{v} / \mathrm{v}$ $\%$ ). It should be noted that 1,6-hexamethylenediamine has two mechanisms to increase the stability of shale cuttings. First, 1,6-hexamethylenediamine is one of the oligomeric cationic amines with two cationic charges. Due to cationic property and size, these particles enter into clay platelets. Hence, water molecules are excluded from clay platelets, so that clay cannot be hydrated (Khodja et al. 2010; Saboori et al. 2018; Zhong et al. 2011). In addition, surfaces and edges of shale have negatively charged in the pH range of 9-11 (Alemdar et al. 2005). Hence,

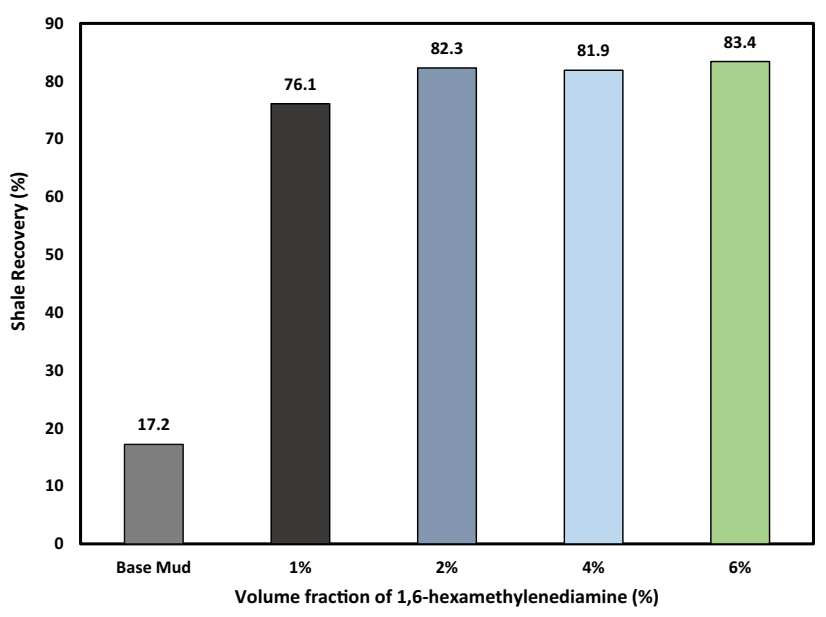

Fig. 13 Shale cutting recoveries of various amounts of 1,6-hexamethylenediamine

electrostatic interaction causes absorbance of 1,6-hexamethylenediamine on the surface of the shale. These two mechanisms tremendously increase the stability of shale cuttings (Zhong et al. 2011). It should be mentioned that there is a specified procedure for shale recovery testing. Before starting the test, all apparatus and equipment such as weighting apparatus, rolling oven, etc. were completely calibrated. In addition, the test was conducted by expert workers very carefully. Therefore, the error of the experiment was kept at the minimum range.

\section{Conclusion}

In this work, the effect of 1,6-hexamethylenediamine on thermal stability of the PAC and shale recovery of heavy weight drilling fluid has been investigated. Laboratory tests 
depict that adding 1,6-hexamethylenediamine has improved rheological properties, reduced fluid loss, and increased shale recovery. The results are explained as follows:

- Adding 1,6-hexamethylenediamine to PAC in drilling fluid has increased rheological properties such as apparent viscosity, plastic viscosity, yield point, and gel strength up to $350^{\circ} \mathrm{F}$.

- Adding 1,6-hexamethylenediamine to PAC in drilling fluid has improved filtration control up to $375^{\circ} \mathrm{F}$.

- 1,6-Hexamethylenediamine in drilling fluid has increased $\mathrm{pH}$ values of heavy weight drilling fluids. The measured $\mathrm{pH}$ values are operationally desirable for drilling fluid.

- Shale recovery of drilling fluids containing 1,6-hexamethylenediamine is extremely increased in contrast to base mud. Base mud's shale recovery was $17.2 \%$, while the drilling fluid containing $2(\mathrm{v} / \mathrm{v} \%)$ of 1,6-hexamethylenediamine has the optimal shale recovery with the amount of $82.3 \%$.

- By analyzing the results, it is concluded that $2(\mathrm{v} / \mathrm{v} \%)$ of 1,6-hexamethylenediamine has the optimal effect on the rheological properties shale stability and fluid loss of heavy weight drilling fluid.

Open Access This article is distributed under the terms of the Creative Commons Attribution 4.0 International License (http://creativeco mmons.org/licenses/by/4.0/), which permits unrestricted use, distribution, and reproduction in any medium, provided you give appropriate credit to the original author(s) and the source, provide a link to the Creative Commons license, and indicate if changes were made.

\section{References}

Abdo J, Haneef MD (2010) Nanoparticles: promising solution to overcome stern drilling problems. In: Nanotech conference and exhibition, Anaheim

Abdou MI, Al-Sabagh AM, Dardir MM (2013) Evaluation of Egyptian bentonite and nano-bentonite as drilling mud. Egypt J Pet 22(1):53-59

Abduo MI, Dahab AS, Abuseda H, AbdulAziz AM, Elhossieny MS (2016) Comparative study of using water-based mud containing multiwall carbon nanotubes versus oil-based mud in HPHT fields. Egypt J Pet 25(4):459-464

Adamson K, George B, Erhu G, Steve H, Colin M, David M, Anver Q (1993) High-pressure, high-temperature well construction. Oilfield Rev 2(3): 15-32

Aftab A, Ismail AR, Ibupoto ZH (2017) Enhancing the rheological properties and shale inhibition behavior of water-based mud using nanosilica, multi-walled carbon nanotube, and graphene nanoplatelet. Egypt J Pet 26(2):291-299

Agin F, Khosravanian R, Karimifard M, Jahanshahi A (2018) Application of adaptive neuro-fuzzy inference system and data mining approach to predict lost circulation using DOE technique (Case study: Maroon oilfield). Petroleum (accepted)
Alemdar A, Öztekin N, Güngör N, Ece ÖI, Erim FB (2005) Effects of polyethyleneimine adsorption on the rheological properties of purified bentonite suspensions. Colloids Surf A 252(2-3):95-108

American Petroleum Institute (2003) Recommended practice for field testing of water-based drilling fluids, 3rd ed. American Petroleum Institute, Washington DC (82 pages ANSI/API 13B-1)

Audibert A, Argillier JF (1995) Thermal stability of sulfonated polymers. In: SPE international symposium on oilfield chemistry. Society of Petroleum Engineers, San Antonio. https://doi. org/10.2118/28953-MS

Azimi Dijvejin Z, Ghaffarkhah A, Vafaie Sefti M, Moraveji MK (2018) Synthesis, structure and mechanical properties of nanocomposites based on exfoliated nano magnesium silicate crystal and poly (acrylamide). J Disper Sci Technol 1:11

Balestrini A, Maas A, Seheult M, Morton EK (2009) Advances in API/ISO standard grade purified poly-anionic cellulose (PAC) and drilling grade xanthan gum (XG) test procedure and specifications definition. In: SPE/IADC drilling conference and exhibition. Society of Petroleum Engineers, Amsterdam. https://doi. org/10.2118/119973-MS

Baller H (1991) North Sea HPHT wells require changes in drilling procedures. Oil Gas J 89(10):12-21

Beg M, Sharma S, Ojha U (2018) Effect of cationic copolyelectrolyte additives on drilling fluids for shales. J Pet Sci Eng 161:506-514

Bruton JR, McLaurine HC (1993) Modified poly-amino acid hydration suppressant proves successful in controlling reactive shales. In: SPE annual technical conference and exhibition. Society of Petroleum Engineers, Houston. https://doi.org/10.2118/26327-MS

Davoodi S, Ramazani SA, Jamshidi S, Jahromi AF (2017) A novel field applicable mud formula with enhanced fluid loss properties in high pressure-high temperature well condition containing pistachio shell powder. J Pet Sci Eng 162:378-385

Dhiman P (2016) Experimental investigation of the influence of various nanoparticles on water-based mud. Master Thesis, University of Alaska. https://dspace31b.library.uaf.edu/handle/11122/7378

Du W, Pu X, Sun J, Luo X, Zhang Y, Li L (2018) Synthesis and evaluation of a novel monomeric amine as sodium montmorillonite swelling inhibitor. Adsorpt Sci Technol 36(1-2):655-668

Fereydouni M, Sabbaghi S, Saboori R, Zeinali S (2012) Effect of polyanionic cellulose polymer nanoparticles on rheological properties of drilling mud. Int J Nanosci Nanotechnol 8(3):171-174

Gholizadeh-Doonechaly N, Tahmasbi K, Davani E (2009) Development of high-performance water-based mud formulation based on amine derivatives. In: SPE international symposium on oilfield chemistry. Society of Petroleum Engineers, Woodlands. https:// doi.org/10.2118/121228-MS

Halali MA, Ghotbi C, Tahmasbi K, Ghazanfari MH (2016) The role of carbon nanotubes in improving thermal stability of polymeric fluids: Experimental and modeling. Ind Eng Chem Res 55(27):7514-7534

Hoelscher KP, De Stefano G, Riley M, Young S (2012) Application of nanotechnology in drilling fluids. In: SPE international oilfield nanotechnology conference and exhibition. Society of Petroleum Engineers, Noordwijk. https://doi.org/10.2118/157031-MS

Ismail AR, Aftab A, Ibupoto ZH, Zolkifile N (2016) The novel approach for the enhancement of rheological properties of waterbased drilling fluids by using multi-walled carbon nanotube, nanosilica and glass beads. J Pet Sci Eng 139:264-275

Jain R, Mahto TK, Mahto V (2016) Rheological investigations of water based drilling fluid system developed using synthesized nanocomposite. Korea Aust Rheol J 28(1):55-65

Kafashi S, Karimi G, Rasaei M (2017a) Evaluation of PAC with nanoclay as drilling mud. Bulletin de la Société Royale des Sciences de Liège. https://doi.org/10.25518/0037-9565.6666 
Kafashi S, Rasaei M, Karimi G (2017b) Effects of sugarcane and polyanionic cellulose on rheological properties of drilling mud: an experimental approach. Egypt J Pet 26(2):371-374

Kelessidis VC, Zografou M, Chatzistamou V (2013) Optimization of drilling fluid rheological and fluid loss properties utilizing PHPA polymer. In: SPE middle east oil and gas show and conference. Society of Petroleum Engineers, Manama. https://doi. org/10.2118/164351-MS

Khodja M, Canselier JP, Bergaya F, Fourar K, Khodja M, Cohaut N, Benmounah A (2010) Shale problems and water-based drilling fluid optimisation in the Hassi Messaoud Algerian oil field. Appl Clay Sci 49(4):383-393

Li MC, Wu Q, Song K, De Hoop CF, Lee S, Qing Y, Wu Y (2015) Cellulose nanocrystals and polyanionic cellulose as additives in bentonite water-based drilling fluids: Rheological modeling and filtration mechanisms. Ind Eng Chem Res 55(1):133-143

Lv KH, Zhong HY, Ren GL, Liu YX (2014) Properties evaluation and application of organic amine inhibitor on the properties of drilling fluids. Open Pet Eng J 7:50-54

Mohammed AS (2017a) Vipulanandan model for the rheological properties with ultimate shear stress of oil well cement modified with nanoclay. Egypt J Pet 27(3):335-347

Mohammed AS (2017b) Effect of temperature on the rheological properties with shear stress limit of iron oxide nanoparticle modified bentonite drilling muds. Egypt J Pet 26(3):791-802

Moraveji MK, Sabah M, Shahryari A, Ghaffarkhah A (2017) Investigation of drill pipe rotation effect on cutting transport with aerated mud using CFD approach. Adv Powder Technol 28(4):1141-1153

Mozaffari S, Tchoukov P, Atias J, Czarnecki J, Nazemifard N (2015) Effect of asphaltene aggregation on rheological properties of diluted athabasca bitumen. Energ Fuel 29(9):5595-5599

Mozaffari S, Tchoukov P, Mozaffari A, Atias J, Czarnecki J, Nazemifard N (2017a) Capillary driven flow in nanochannels-application to heavy oil rheology studies. Colloids Surf A 513:178-187

Mozaffari S, Li W, Thompson C, Ivanov S, Seifert S, Lee B, Kovarik L, Karim AM (2017b) Colloidal nanoparticle size control: experimental and kinetic modeling investigation of the ligand-metal binding role in controlling the nucleation and growth kinetics. Nanoscale 9(36):13772-13785

Mozaffari S, Li W, Thompson C, Ivanov S, Seifert S, Lee B, Kovarik L, Karim AM (2018) Ligand-mediated nucleation and growth of palladium metal nanoparticles. J Vis Exp 25(136):e57667

Nasiri A, Ghaffarkhah A, Moraveji MK, Gharbanian A, Valizadeh M (2017) Experimental and field test analysis of different loss control materials for combating lost circulation in bentonite mud. J Nat Gas Sci Eng 31:1-8

Nasiri A, Shahrabi MJ, nik MA, Heidari H, Valizadeh M (2018) Influence of monoethanolamine on thermal stability of starch in water based drilling fluid system. J Pet Explor Dev 45(1):167-171

Noah AZ, El Semary MA, Youssef AM, El-Safty MA (2017) Enhancement of yield point at high pressure high temperature wells by using polymer nanocomposites based on $\mathrm{ZnO} \& \mathrm{CaCO}_{3}$ nanoparticles. Egypt J Pet 26(1):33-40

Onuoha IEO, Bilgesu HI, Ameri S (2011) Study of drilling fluid additives and their impact on smectite inhibition, marcellus shale inhibition, and filtration and rheological properties of bentonite based drilling fluids. In: SPE eastern regional meeting. Society of Petroleum Engineers, Columbus. https://doi.org/10.2118/149271-MS

Oswald RJ, Knox DA, Monem MR (2006) Taking nondamaging fluids to new extremes: formate-based drilling fluids for high-temperature reservoirs. In: SPE international symposium and exhibition on formation damage control. Society of Petroleum Engineers, Pakistan. https://doi.org/10.2118/98391-MS

Patel AD (2009) Design and development of quaternary amine compounds: shale inhibition with improved environmental profile. In:
SPE international symposium on oilfield chemistry. Society of Petroleum Engineers, Woodlands. https://doi.org/10.2118/12173 7-MS

Peng B, Luo PY, Guo WY, Yuan Q (2013) Structure-property relationship of polyetheramines as clay-swelling inhibitors in water-based drilling fluids. J Appl Polym Sci 129(3):1074-1079

Plank JP, Gossen FA (1991) Visualization of fluid-loss polymers in drilling-mud filter cakes. SPE Drill Eng 6(03):203-208

Ponmani S, Nagarajan R, Sangwai JS (2016) Effect of nanofluids of $\mathrm{CuO}$ and $\mathrm{ZnO}$ in polyethylene glycol and polyvinylpyrrolidone on the thermal, electrical, and filtration-loss properties of waterbased drilling fluids. SPE J 21(02):405-415

Qu Y, Lai X, Zou L, Su YN (2009) Polyoxyalkyleneamine as shale inhibitor in water-based drilling fluids. Appl Clay Sci 44(3-4):265-268

Saboori R, Sabbaghi S, Kalantariasl A, Mowla D (2018) Improvement in filtration properties of water-based drilling fluid by nanocarboxymethyl cellulose/polystyrene core-shell nanocomposite. J Pet Explor Prod Technol 8(2):445-454

Sensoy T, Chenevert ME, Sharma MM (2009) Minimizing water invasion in shales using nanoparticles. In: SPE annual technical conference and exhibition. Society of Petroleum Engineers, New Orleans. https://doi.org/10.2118/124429-MS

Shahbazi K, Arshadi A, Valizadeh M (2018) An experimental study of the effect of amines on polymer efficiency and thermal stability of water-based drilling fluid. J Pet Sci Technol 8(2):29-37

Shakib JT, Kanani V, Pourafshary P (2016) Nano-clays as additives for controlling filtration properties of water-bentonite suspensions. J Pet Sci Eng 138:257-264

Thomas DC (1982) Thermal stability of starch-and carboxymethyl cellulose-based polymers used in drilling fluids. SPE J 22(02):171-180

Toka B, Toka N (2015) Preparing drilling fluid compositions for geothermal reservoirs. In: Proceedings world geothermal congress, Melbourne, April 19. https://pangea.stanford.edu/ERE/db/WGC/ papers/WGC/2015/21006.pdf

Van Oort E (2003) On the physical and chemical stability of shales. J Pet Sci Eng 38(3-4):213-235

Van Krevelen DW, Te Nijenhuis K (2009) Properties of polymers: their correlation with chemical structure; their numerical estimation and prediction from additive group contributions. Elsevier, Amsterdam

Van Oort E, Bland RG, Howard SK, Wiersma RJ, Roberson L (1997) Improving HPHT stability of water based drilling fluids. In: SPE/IADC drilling conference. Society of Petroleum Engineers, Amsterdam. https://doi.org/10.2118/37605-MS

Villada Y, Gallardo F, Erdmann E, Casis N, Olivares L, Estenoz D (2017) Functional characterization on colloidal suspensions containing xanthan gum (XGD) and polyanionic cellulose (PAC) used in drilling fluids for a shale formation. Appl Clay Sci 149:59-66

Wang L, Liu S, Wang T, Sun D (2011) Effect of poly (oxypropylene) diamine adsorption on hydration and dispersion of montmorillonite particles in aqueous solution. Colloids Surf A 381(1-3):41-47

William JK, Ponmani S, Samuel R, Nagarajan R, Sangwai JS (2014) Effect of $\mathrm{CuO}$ and $\mathrm{ZnO}$ nanofluids in xanthan gum on thermal, electrical and high pressure rheology of water-based drilling fluids. J Pet Sci Eng 117:15-27

Wong KV, De Leon O (2012) Applications of nanofluids: current and future. Adv Mech Eng 2:519-659

Xie G, Luo P, Deng M, Su J, Wang Z, Gong R, Xie J, Deng S, Duan Q (2017) Intercalation behavior of branched polyethyleneimine into sodium bentonite and its effect on rheological properties. Appl Clay Sci 141:95-103

Zakaria M, Husein MM, Harland G (2012) Novel nanoparticle-based drilling fluid with improved characteristics. In: SPE international oilfield nanotechnology conference and exhibition. Society of

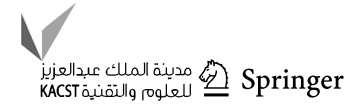


Petroleum Engineers, Noordwijk. https://doi.org/10.2118/15699 2-MS

Zhong H, Qiu Z, Huang W, Cao J (2011) Shale inhibitive properties of polyether diamine in water-based drilling fluid. J Pet Sci Eng 78(2):510-515

Zhong H, Qiu Z, Huang W, Cao J (2012) Poly (oxypropylene)-amidoamine modified bentonite as potential shale inhibitor in waterbased drilling fluids. Appl Clay Sci 67:36-43

Zhong H, Qiu ZS, Huang WA, Cao J, Wang FW, Xie BQ (2013) Inhibition comparison between polyether diamine and quaternary ammonium salt as shale inhibitor in water-based drilling fluid. Energy Source Part A 35(3):218-225

Zhong H, Qiu Z, Huang W, Sun D, Zhang D, Cao J (2015a) Synergistic stabilization of shale by a mixture of polyamidoamine dendrimers modified bentonite with various generations in water-based drilling fluid. Appl Clay Sci 114:359-369

Zhong H, Qiu Z, Sun D, Zhang D, Huang W (2015b) Inhibitive properties comparison of different polyetheramines in water-based drilling fluid. J Nat Gas Sci Eng 26:99-107

Zhong H, Qiu Z, Zhang D, Tang Z, Huang W, Wang W (2016) Inhibiting shale hydration and dispersion with amine-terminated polyamidoamine dendrimers. J Nat Gas Sci Eng 28:52-60

Publisher's Note Springer Nature remains neutral with regard to jurisdictional claims in published maps and institutional affiliations. 